\title{
DETERMINANTS OF EMPLOYEE JOB SATISFACTION: EVIDENCE FROM THE UNIVERSITY OF KARACHI, PAKISTAN
}

\author{
Sabbor Hussain ${ }^{1 *}$, John Francis Diaz ${ }^{2}$ \\ ${ }^{1}$ Doctor of Philosophy in Business, College of Business, Chung Yuan Christian University, Taoyuan City, Taiwan \\ ${ }^{2}$ Department of Finance and Accounting, Asian Institute of Management, Makati City, Philippines 1630 \\ *Corresponding author; Email: ${ }^{1 *}$ sabborhussain@gmail.com; ${ }^{2}$ jdiaz@aim.edu, johnfrancis_diaz@yahoo.com
}

\begin{abstract}
The study identified factors affecting employee job satisfaction in the University of Karachi. The research collected data using survey questionnaire consisting of twenty nine questions. The study found that a generous rewards and compensation packages lead to job satisfaction and are affected by promotion and job security. Good working relationship with co-workers also contributes to employee job satisfaction. Also, it is found that good working environment also contributes to employee motivation, and is influenced by better facilities, and training and development. Finally, good supervision provides motivation that enhances the quality of output and employee performance. The findings are important, because it is well-established in the literature that job satisfaction and employee motivation play a major role in increasing productivity of employees and profitability of the organization.
\end{abstract}

Keywords: Job satisfaction, employee motivation, employee retention, work performance.

\section{Introduction}

Human resource is a vital part of any organization, without the necessary skills and motivations of employees, objectives of the organization will be difficult to meet. Thus, organizations, be it private or public, has to always look after the welfare of its employees. Satisfied and well-motivated employees result in the overall productivity of any organization; and those companies who managed this asset very well are those who are profitable (e.g., Google and Starbucks). Employee job satisfaction is a part of management, which can be considered as the back bone of any organization. Job satisfaction has been major objective of organizations, because productivity of employees and profitability of the firm depends on how motivated employees are in doing their part. Employees who are not satisfied with their job are always less productive.

In the literature, scholars (e.g., Chandan, 2005; Sokoya, 2000) of human resource management suggested many causes and effects of both job satisfaction and dissatisfaction, and one main cause is employee's attitude towards work. Other factors considered are working conditions and the overall support of management, which all affect the productivity of employees, absenteeism rates, and loyalty to the organization. Satisfied employees are more productivity and have less absences compared to those who are not satisfied with their jobs. Sokoya (2000) mentioned numbers of factor like age, gender, education, and income status that affect employee satisfaction. Some organizations like the multinationals, hire more young and fresh graduates are hired, because they are more driven and motivated to prove themselves than their older counterparts. Highly educated employees are also more satisfied, because they are always up to the challenge, and are not easily discourage with the complexity of work. High income employees on the other hand also have higher job satisfaction, because of the high position and better sense of accomplishment in an organization.

Financial incentives also motivate employees, because of the sense of reward and achievement given to them for the successful completion of the task (Voydanoff, 1980). Supervision is one more important factor in maintaining job satisfaction. The performance and motivation of employees can also depend on their healthy relationship with their supervisor. Good supervision brings better communication, which helps in the quicker and better ways of solving work problems, because of clearer instructions and identifying suitable employees to accomplish certain specific tasks. Based on Harrick, Vanek, and Michlitsch (1986), a conducive working environment is also a determinant of job satisfaction. It starts in the recruitment and orientation 
process, wherein employees feel the support of the management on how they can better start in accomplishing their new jobs. It also helps when new recruits are mentored by a fellow employee, are supported by seasoned employees in an organization.

This paper attempts to determine employee job satisfaction of one of the premier educational institution in Pakistan, the University of Karachi. The university was founded in 1951 and is situated in the industrial and most important metropolitan area of Pakistan. The University of Karachi has number of departments related to administration (i.e., Management, Commerce and Public Administration), natural sciences (i.e. Biology, Physics, Chemistry, and Mathematics) and the Humanities.

The mission of the University of Karachi is to build a nation through education, through the use of its large facilities and infrastructure. Graduates of the university had held important positions and were prominent figures in Pakistan, some are also successful individuals abroad. Students come from different areas of the country as well as from other places like Africa and Middle East. As of the current record, the university already has 25,000 students being supported by 1,150 teaching, and 3,050 non-teaching staff. Employees play a very important role and receive training and development depending on the department they are in, and their job descriptions. The University of Karachi strictly follows on its mandate not to only educate their students but also train its workforce, and treated as the most basic asset of the university. The university puts importance to its employee's job satisfaction.

The general problem statement of this research paper is to identify what factors affect the job satisfaction of employees in the University of Karachi. To help answer this statement, the study aims to specifically;

a) Know the primary determinants, and the relationship of these factors that influence employees job satisfaction; and

b) Identify environmental factors that are directly related to achieve satisfaction. In attempting to satisfy these objectives, number of limitations were encountered by this study. For example, time considerations limited the paper in covering a larger number of the university's employee population; administrative and political considerations to be observed, which limited the resources given by the university; and employees' lack of cooperation and hesitation, which restricted some answers to related question

This section summarizes related literature that discusses factors affecting employee job satisfaction.
The set of literature was divided in three parts: a) individual and personal factors; b) environment and relationship factors; and c) compensation and rewards. Chandan (2005) argued that satisfied employees are more productive, and the extent of positive feelings or attitude that employees have towards their job also lead to job satisfaction. The author also concluded that some factors that lead to satisfied employees are their compensation, working environment and relationship with superiors. Sokoya (2000) considered a number of factors that affect job satisfaction. For example, age can be factor, because older employees are more $p$ reoccupied with balancing their family lives and work, while younger employees have fewer concerns. Gender on the other hand is another factor, wherein females have more emotional and physical requirements than males that may impact job performance; males on the other hand are more careless and less conscientious than females in general. The level of education also provides good training to well-educated individuals. They become better in handling complex situations than their lesseducated counterparts. Robbins and Sanghi (2006) argued that workers with positive attitude and are selfmotivated are better in handling more complicated tasks than those who are not, because employees with negative attitude and less motivated are more likely to be overwhelmed by job challenges and will less likely find solutions.

Harrick et al. (1986) concluded that employees are positively influenced by the good environment. A conducive working environment coupled with skills training provide employees with satisfaction that leads to productivity in the workplace. Eadie and Canton (2002) focused on the relationship of the supervisor and employees. The author argued that is an employee is supervised in better way, he/she will be have a more positive attitude in handling the task. The knowledge and leadership skills of the supervisor on employees and the organization have a large impact on the job satisfaction of employees. Peterson and Luthans (2006) identified relationship with co-workers also affect job satisfaction. If employees have good working relationships with their co-workers, their morale and behavior towards work are more positive, which leads to more productivity. Voydanoff (1980) on the other hand, identified financial compensation as one of the most important factor to attain job satisfaction Nugroho, Kaihatu, and Kartika (2014) find out the effect of management's controllable factor, called internal factor or structural variable, identifies high salaries and fellow employees' behavior contribute their job satisfaction. Companies that provide 
high compensation to their employees are also profitable because productivity of employees increases. In a related study by Watson, Storey, Wynarczyk, Keasey, and Short (1996), the author argued that a fair reward system and the entitlements that they are receiving from the company satisfy employees, will more likely stay in their job. Andreani, and Petrik (2016) research study contribute that there is significant and positive effect of a good leadership on employee performance.

\section{Research Method}

The primary data was collected using a survey form, "Employees Job Satisfaction of University of Karachi". The Likert scale was used to collect and analyze the answers of survey participants. The University of Karachi has a total of 4,200 employees, 1,150 of which are teaching staff, and 3,050 are non-teaching staff. Given the limitations stated in the Introduction, a total of 100 valid samples were collected, $44 \%$ of which were teaching staff, and $56 \%$ were non-teaching staff; and $40 \%$ were female, and $60 \%$ were male. Excel spreadsheets were used to tabulate, and SPSS was used to run and analyze the data.

Employee's job satisfaction is the dependent variable while supervision, working itself (or attitude towards work), working environment, monetary rewards and relationship with coworkers are the independent variables, which may either have positive or negative relationship with job satisfaction. The study formulated the following hypotheses:

$H_{l}$ : Good supervision has a positive influence on employee job satisfaction.

$\mathrm{H}_{2}$ : Positive attitude and motivation towards work have positive relationship with employee job satisfaction.

$H_{3}$ : Conducive working environment has a positive effect on employee job satisfaction.

$H_{4}$ : Above average financial rewards and compensation have positive influence on employee job satisfaction.

$H_{5}$ : Good working relationship with supervisors and co-workers has a positive effect on employee job satisfaction.

To collect the research data, a survey questionnaire consisting of 29 questions were used and apply the correlation to find out the relationship and association between the dependent and independent variables. Below Figure 1 shows the schematic diagram representing the relationship of independent variables to the dependent variable with the corresponding hypotheses.

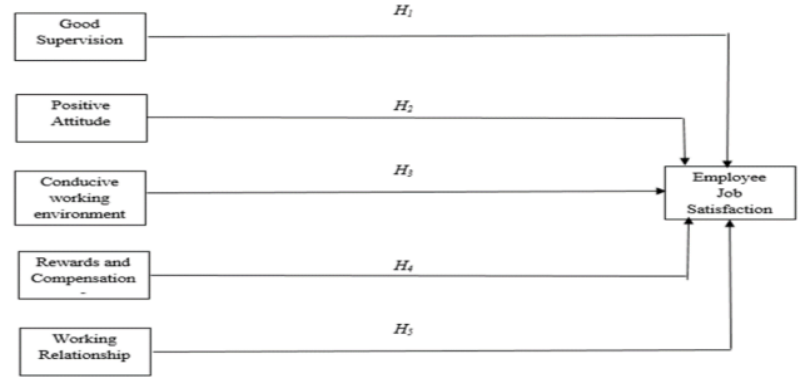

Figure 1. Five independent variables affecting employee job satisfaction.

\section{Empirical Results}

Table 1 illustrates the age group of the respondents, and shows that majority of the employees surveyed are below the 40 years old. Employees who are from 21 to 30 years old comprised $48 \%$ of the data, while those from 31 to 40 years old covered $40 \%$ of the valid respondents.

Table 1

Age Distribution of Respondents

\begin{tabular}{|c|c|c|c|c|c|}
\hline & & Frequency & Percent & $\begin{array}{c}\text { Valid } \\
\text { Percent }\end{array}$ & $\begin{array}{l}\text { Cumulative } \\
\text { Percent }\end{array}$ \\
\hline \multirow{3}{*}{$\begin{array}{l}\text { Valid } \\
\text { Respondents }\end{array}$} & $21-30$ & 48 & 48.0 & 48.0 & 48.0 \\
\hline & $31-40$ & 40 & 40.0 & 40.0 & 88.0 \\
\hline & $\begin{array}{l}41 \text { and above } \\
\text { Total }\end{array}$ & $\begin{array}{ll}12 \\
100\end{array}$ & $\begin{array}{c}12.0 \\
100.0\end{array}$ & $\begin{array}{c}12.0 \\
100.0\end{array}$ & 100.0 \\
\hline
\end{tabular}

Table 2 shows the designation of respondents from the University of Karachi. Teaching staff comprised $44 \%$ of the respondents, while the remaining are nonteaching staff. The data slightly resembles the distribution of employees in the University wherein majority are non-teaching staff. Also, another reason is the availability of non-teaching staff to serve as respondents of the study.

Factors of age and gender were considered by Sokoya (2000), and related these factors to more demands of balancing family lives and work for older workers; emotional and physical requirements of female workers, and the tendency of male workers to be riskier, more careless and less conscientious than females in general.

Table 2 Designation Distribution of Respondents

\begin{tabular}{lcccc}
\hline University Staff & Frequency & Percent & $\begin{array}{c}\text { Valid } \\
\text { Percent }\end{array}$ & $\begin{array}{c}\text { Cumulative } \\
\text { Percent }\end{array}$ \\
\hline Teaching Staff & 44 & 44.0 & 44.0 & 44.0 \\
Non-Teaching Staff & 56 & 56.0 & 56.0 & 100.0 \\
Total & 100 & 100.0 & 100.0 & \\
\hline
\end{tabular}


Tables 3 to 7 describe the factors that affect employee job satisfaction in the University of Karachi. Table 3 explains that good supervision contributes to employee job satisfaction by providing motivation that enhances the quality of output and performance of employee. A good supervisor helps employees to achieve their career goals, and create a more rewarding working environment. Based on the results of this study, there is good positive relationship between job satisfaction and supervision that is 0.71 with significant $p$ value 0.009 it means that supervising is directly positive effects on employee job satisfaction.

The relationship with immediate supervisor in the University of Karachi found that $89(54+35)$ employees perceive relationship with supervisor generally gives them job satisfaction. However, the level of praise and appreciation is not enough in the university, because a little fewer than half or $48(32+16)$ respondents only responded affirmatively. On the other hand, the respect personal and domestic affairs are also at least agreed upon by $56(43+13)$ employees. Lastly, employees experiencing good work-life balance and personal wellbeing are also well-accepted by $79(57+22)$ employees. Therefore, we can generally see that good supervision is highly influential to the job satisfaction and overall wellbeing of employees in the University of Karachi. These findings are in-line with the initial findings of Eadie and Canton (2002), who argued that good employee supervision have a more positive attitude in handling the task

Table 3

Good Supervision, Satisfaction and Related Factors

\begin{tabular}{lccc}
\hline \multicolumn{1}{c}{ Good Supervision } & Agree & $\begin{array}{c}\text { Strongly } \\
\text { agree }\end{array}$ & Others \\
\hline Satisfied with job supervisor & 54 & 35 & 11 \\
Supervisor appreciates and praise & 32 & 16 & 52 \\
Respect personal and domestic affairs & 43 & 13 & 44 \\
$\begin{array}{l}\text { Work-life balance and personal well- } \\
\text { being }\end{array}$ & 57 & 22 & 21 \\
\hline
\end{tabular}

Table 3a

Correlations between Employees Job Satisfaction and Good Supervision

\begin{tabular}{llcc}
\hline & & $\begin{array}{c}\text { Job } \\
\text { Satisfaction }\end{array}$ & $\begin{array}{c}\text { Good } \\
\text { Supervision }\end{array}$ \\
\hline Job Satisfaction & Pearson Correlation & 1 & $0.718^{*}$ \\
& Sig. (2-tailed) & & 0.009 \\
& $N$ & 100 & 100 \\
Good Supervision & Pearson Correlation & $0.718^{*}$ & 1 \\
& Sig. (2-tailed) & 0.009 & \\
& $N$ & 100 & 100 \\
\hline
\end{tabular}

Table 4 shows that positive attitude and motivation towards work have positive relationship with employee job satisfaction. Based on the results of this study, positive attitude and motivation are affected by career growth, office politics and flexible work loads. The positive attitude of employees in the University of Karachi found that $62(44+18)$ Employees perceive that career opportunities gives them more positive outlook about their jobs. However, political parties and bureaucracy in the university have somewhat a negative effect, because a little over than half or $51(36+15)$ respondents only responded affirmatively. Lastly, flexible duties and work assignment are also at least agreed upon by 53 (38 +15 ) employees. Thus, we can still generally say that positive attitude and motivation towards work of the employees in the University of Karachi are influenced by career growth, office politics and flexible work loads.

The below correlation Table 4a results show that there is positive strong relationship between variable Positive attitude and motivation with employees' job satisfaction which is 0.819 . The $p$-value also represents that there is lack of coordination between Positive attitude and motivation with their corresponding employees

\section{Table 4}

Positive Attitude, Motivation and Related Factors

\begin{tabular}{lccc}
\hline Positive attitude and motivation & Agree & $\begin{array}{c}\text { Strongly } \\
\text { agree }\end{array}$ & Others \\
\hline Career Growth & 44 & 18 & 38 \\
Political parties influencing job & 36 & 15 & 49 \\
Flexible duties and assignment & 38 & 15 & 47 \\
\hline
\end{tabular}

Table 4a

Correlations between Employees Job Satisfaction and Positive Attitude and Motivation

\begin{tabular}{llcc}
\hline & $\begin{array}{c}\text { Job } \\
\text { Satisfaction }\end{array}$ & $\begin{array}{c}\text { Positive } \\
\text { Attitude and } \\
\text { Motivation }\end{array}$ \\
\hline Job & Pearson Correlation & 1 & $0.819^{*}$ \\
Satisfaction & Sig. (2-tailed) & 100 & 0.220 \\
& $N$ & $0.819^{*}$ & 100 \\
Positive & Pearson Correlation & 0.220 & 1 \\
Attitude and & Sig. (2-tailed) & 100 & 100 \\
Motivation & $N$ & & \\
\hline
\end{tabular}

Table 5 illustrates that a good working environment contributes to employee job satisfaction, and influenced by better facilities, proper rules and regulation, and training and development. Based on the results of this research, good working environment and a conducive work place positively received by $58(38+$ 
20) employees. On one hand, the conflict management system in the University of Karachi is found to be satisfactory for $54(40+14)$ employees. However, employees' involvement in decision-making is not enough in the university, because a little fewer than half or $48(35+13)$ employees only responded affirmatively. The SPSS results also shows positive relationship between dependent variable and conducive working environment.

The study suggests that the university should put in place a better decision-making process, wherein employees or an employee representative has a voice on decision-making. Lastly, employees undergoing trainings and skills development are well-received by 61 (34 + 27) employees. Therefore, this research finds that better facilities, proper rules and regulation, training and development contribute a better working environment in the University of Karachi. These results are consistent with the initial observations of Chandan (2005) and Sokoya (2000) regarding the positive effects of attitude, and skills growth in the job satisfaction of employees; and by Harrick et al.'s (1986) conclusion that employees are positively influenced by the good environment.

Table 6 explain that generous rewards and compensation packages in every organization contribute to employee job satisfaction, and influenced by recognition, promotion and job security. Based on the results of this research, employees receiving rewards and recognition are also received by $52(37+15)$ employees.

Table 5

Conducive Working Environment and Related Factors

\begin{tabular}{lccc}
\hline \multicolumn{1}{c}{$\begin{array}{c}\text { Conducive Working } \\
\text { Environment }\end{array}$} & Agree & $\begin{array}{c}\text { Strongly } \\
\text { Agree }\end{array}$ & Others \\
\hline Environment at work place & 38 & 20 & 42 \\
Conflict handling system & 40 & 14 & 46 \\
$\begin{array}{l}\text { Employee involvement in } \\
\quad \text { decision making }\end{array}$ & 35 & 13 & 52 \\
Training and development & 34 & 27 & 39 \\
\hline
\end{tabular}

Table 5a

Correlations between Employees Job Satisfaction and Conducive Working Environment

\begin{tabular}{llcc}
\hline & & $\begin{array}{c}\text { Job } \\
\text { Satisfaction }\end{array}$ & $\begin{array}{c}\text { Conducive } \\
\text { Working } \\
\text { Environment }\end{array}$ \\
\hline Job & Pearson Correlation & 1 & 0.512 \\
Satisfaction & Sig. (2-tailed) & 100 & 0.000 \\
& $N$ & 0.512 & 100 \\
Conducive & Pearson Correlation & 0.000 & $\mathbf{1}$ \\
Working & Sig. (2-tailed) & 100 & 100 \\
Environment & $N$ & &
\end{tabular}

On one hand, the promotion and appraisal system in the University of Karachi is found to be also satisfactory for $52(39+13)$ employees. Lastly, employees having employed by the government are well-received by $61(42+19)$ employees. One possible reason for this high acceptance is that being an employee of a government organization, employees feel more security with their job tenure, benefits and pension. Therefore, this research finds that generally, better recognition, promotion and job security contribute to having a better working rewards and compensation packages in the University of Karachi. These findings indicate shown in Table 6a that there is weak positive significance association between Rewards and Compensation and employees Job Satisfaction which is 0.23. Further it reveals that there is lack of association between the dependent variable and independent variable. The results are consistent with the earlier study of Voydanoff (1980) stating that compensation and incentives motivate employees.

Table 6

Rewards, Compensation and Related Factors

\begin{tabular}{lccc}
\hline Rewards and Compensation & Agree & $\begin{array}{c}\text { Strongly } \\
\text { Agree }\end{array}$ & Others \\
\hline Reward and recognition & 37 & 15 & 48 \\
Promotion and appraisals & 39 & 13 & 48 \\
$\quad$ system & 42 & 19 & 39 \\
Secure job &
\end{tabular}

Table 6a

Correlations between Employees Job Satisfaction and Conducive Working Environment

\begin{tabular}{llcc}
\hline & & $\begin{array}{c}\text { Job } \\
\text { Satisfaction }\end{array}$ & $\begin{array}{c}\text { Rewards and } \\
\text { Compensation }\end{array}$ \\
\hline Job Satisfaction & Pearson Correlation & 1 & $0.230^{*}$ \\
& Sig. (2-tailed) & & 0.022 \\
& $N$ & 100 & 100 \\
Rewards and & Pearson Correlation & 0.230 & 1 \\
Compensation & Sig. (2-tailed) & 0.022 & \\
& $N$ & 100 & 100 \\
\hline
\end{tabular}

Table 7 illustrates that good working relationship with fellow employees contributes to employee job satisfaction, and influenced by respect among others, job retention, and availability of job openings. Based on the results of this research, respect among co-workers in the office received by a lower than half $49(33+15)$ Employees. On one hand, the job retention system in the University of Karachi is found to be satisfactory for 54 $(38+16)$ employees. Also, employees value the availability of open job positions in the university job market, 
and $55(42+13)$ employees responded affirmatively. The correlation Table 7a indicates that there is strong positive significance association between variable working relationship and employees job satisfaction which is 0.82 . Further it indicates that there is strong correlation between their corresponding working relationship. Lastly, the overall job satisfaction in the university are well-received by $59(42+17)$ employees. Therefore, this research finds that respect among others, job retention, and availability of job openings. To having a better working relationship in the University of Karachi. These results are consistent with the initial findings of Peterson and Luthans (2006) who identified that good working relationship with co-workers has positive effect on job satisfaction.

Table 7

Working Relationship and Related Factors

\begin{tabular}{lccc}
\hline \multicolumn{1}{c}{ Working Relationship } & Agree & $\begin{array}{c}\text { Strongly } \\
\text { Agree }\end{array}$ & Others \\
\hline Respect of co-workers & 33 & 16 & 51 \\
Job retention & 38 & 16 & 46 \\
Chance of finding same & 42 & 13 & 45 \\
$\quad$ position in market & & & \\
Overall job ratification & 42 & 17 & 41 \\
\hline
\end{tabular}

Table 7a

Correlations between Employees Job Satisfaction and Working Relationship

\begin{tabular}{llcc}
\hline & & $\begin{array}{c}\text { Job } \\
\text { Satisfaction }\end{array}$ & $\begin{array}{c}\text { Working } \\
\text { Relationship }\end{array}$ \\
\hline Job Satisfaction & Pearson Correlation & 1 & 0.824 \\
& Sig. (2-tailed) & & 0.000 \\
Working & $N$ & 100 & 100 \\
Relationship & Pearson Correlation & 0.824 & 1 \\
& Sig. (2-tailed) & 0.000 & \\
& $N$ & 100 & 100 \\
\hline
\end{tabular}

\section{Conclusions}

This paper studied factors affecting employee job satisfaction in the University of Karachi Pakistan. The research collected data using survey questionnaire consisting of twenty-nine questions. The importance of this study stems out of the idea that satisfied and wellmotivated employees can increase productivity of any organization. The study found that good supervision contributes to employee job satisfaction by providing motivation that enhances the quality of output and performance of employee. It is concluded that a good supervisor helps employees to achieve their goals, and create a more rewarding working environment. Positive attitude and motivation are affected by career growth, office politics and flexible work loads.
Furthermore, it is discovered that good working environment contributes employee job satisfaction, and it's influenced by better facilities, proper rules and regulation, training and development. Generous rewards and compensation packages. Contribute, and is influenced by recognition, promotion and job security. Another factor is good working relationship with fellow employees contributes to employee job satisfaction, and influenced by respect among others, job retention, and availability of job openings. The above findings satisfied the primary objectives of the study in identifying factors that influence employees' job satisfaction; and found environmental factors that are related to employee motivation. These results may also apply and helpful to improve the performance of Educational institutions, banking industry, hospitals, manufacturing industries, railways and so many other organizations.

\section{References}

Andreani, F., \& Petrik, A. (2016). Employee performance as the impact of transformational leadership and job satisfaction in PT Anugerah Baru Denpasar. Jurnal Manajemen Kewirausahaan, 18(1), 25-32. https://doi.org/10.9744/jmk.18.1.25-32

Chandan, J. S. (2005). Organization behaviour. Third Edition. New Delhi, India: Vikas Publishing.

Eadie, T. \& Canton, R. (2002). Practicing in a context of ambivalence: The challenge for youth justice workers. Youth Justice, 2(1), 14-26. https://doi.org/ $10.1177 \% 2$ F147322540200200103

Harrick, E. J., Vanek, G. R., \& Michlitsch, J. F. (1986). Alternative work schedules, productivity, leave usage, and employee attitude. Public Personal Management Journal, 15(2), 159-169. https://doi. org/10.1177\%2F009102608601500206

Nugroho, A., Kartika, E. W., \& Kaihatu, T. S. (2014). structural variable on the job satisfaction of 4 and 5 starred hotel employees in Surabaya. Jurnal Manajemen Kewirausahaan, 16(2), 103-110.

Peterson, S. J. \& Luthans, F. (2006). the impact of financial and nonfinancial incentives on business unit outcomes over time. Journal of Applied Psychology, 91(1), 156-165. https://doi.org/10.1037/ 00 21-9010.91.1.156

Robbins, S. P., \& Sanghi, S. (2006). Organizational behavior. $11^{\text {th }}$ Edition. Delhi: Dorling Kindersley (India) Pvt. Ltd.

Sokoya, S. K. (2000). Personal predictors of job satisfaction for the public sector manager (Implications for Management practice and development in 
developing economy). The Journal of Business in Developing Nations, 4(1), 40-53.

Voydanoff, P. (1980). Perceived job characteristics and job satisfaction among men and women. Psychology of Women Quarterly, 5(2), 177-185. https://psycnet.apa.org/doi/10.1111/j.1471-6402. 1980. tb00954.x
Watson, R., Storey, D., Wynarczyk, P., Keasey, K., \& Short, H.(1996). The relationship between job satisfaction and managerial remuneration in small and medium-sized enterprises: An empirical test of 'comparison income' and 'equity theory' hypotheses. Applied Economics, 28(5), 567-576. DOI: $10.1080 / 00036849600000036$ 